\title{
МОВЛЕННСВА КОМПЕТЕНТНІСТЬ У СТРУКТУРІ ПІДГОТОВКИ КОНКУРЕНТОЗДАТНИХ ФАХІВЦІВ У ВНЗ УКРАЇНИ
}

Мудра С. В. Мовленнєва компетентність у структурі підготовки конкурентоздатних фахівців у ВНЗ України.

Створення умов для отримання конкурентних переваг в світі $€$ головною умовою економічної і соціальної стабільності України. Очікувані зміни можливі лише за умови підвищення продуктивності праці, що, у свою чергу, залежить від наявності на вітчизняному ринку праці сучасних висококваліфікованих фахівців. Отже, будь-які трансформаційні зміни в економіці неможливі без реформування та модернізації підготовки конкурентоздатних фахівців.

Ключові слова: мовленнєва компетентність, компетентність, якість, якість освіти, особистість, соціум, вищий навчальний заклад, конкурентоздатний фахівець.

Мудра С. В. Речевая компетентность в структуре подготовке конкурентоспособных специалистов в вузах Украины.

Создание условий для получения конкурентных преимуществ в мире является главным условием экономической и социальной стабильности Украины. Ожидаемые изменения возможны лишь при условии повышения производительности труда, что, в свою очередь, зависит от наличия на отечественном рынке труда современных высококвалифицированных специалистов. Итак, любые трансформационные изменения в экономике невозможны без реформирования и модернизации подготовки конкурентоспособных специалистов.

Ключевые слова: речевая компетентность, компетентность, качество, качество образования, личность, социум, высшее учебное заведение, конкурентоспособный специалист.

Mudra S. V. Speech competence in the structure of the training of competitive specialists in higher educational institutions of Ukraine

Creating the conditions for competitive advantage in the world is the main condition for economic and social stability in Ukraine. Expected changes are possible only if the level () С. В. Мудра, 2014. 
of labor productivity, which in turn depends on the presence in the domestic labor market modern highly qualified specialists. Thus, any transformations in economy is impossible without reforming and modernizing training competitive specialists.

Key words: speech competence, competence, quality, quality, identity, society, institution of higher education, competitive specialist.

Найважливішими умовами розвитку суспільства нової формації є створення інноваційно якісної системи вищої освіти і перехід до економіки, основою якою повинно бути ефективне використання на практиці набутих знань й умінь. А це є головним стрижнем реалізації компетентісного підходу до навчання. Одним зі структурних компонентів такого підходу є проблема навчання мов, яка упродовж XX століття набула очевидної та об'єктивної актуалізації завдяки інтенсивному розвитку і масштабним досягненням психології, соціології, кібернетики, теорії комунікації. Процесом інтегрування різноманітної наукової інформації, на засадах якої окреслилися вимоги до інтелектуальнопрофесійного рівня фахівця, зумовлено появу та введення в науковий обіг таких нових понять, як мовленнєва, комунікативна компетентність, лінгвістична компетентність. Саме 3 цими видами компетентності найчастіше пов'язують надто складний феномен опановування мови спеціальності, ураховуючи теоретичні лінгводидактичні засади навчання спілкуванню рідною та / або нерідною мовою професійного спрямування в обох (усній та письмовій) іï формах. Отже, опанування у ВНЗ мови спеціальності - це засвоєння передусім наукового стилю як функціонального різновиду національної літературної мови в межах обраної галузі знань, зокрема нормативних зразків наукових текстів на всіх рівнях їх ієрархічної організації, а також формування навиків й умінь iз таких актуальних видів професійної мовленнєвої діяльності, як продукування та компресія наукової інформації за фахом у вигляді плану, тез, конспекту, анотації, реферату, рецензії, повідомлення, доповіді, курсової роботи, наукової роботи, статті тощо.

Аналіз попередніх досліджень. Для більш адекватного і повного розуміння проблеми забезпечення якості освіти досліджено фактори новизни в наявних іiі наукових обгрунтуваннях.

Філософський підхід до тлумачення поняття «якість» розкриває розуміння його як внутрішьої субстанційної характеристики об'єкта і визначається тим, що об'єктивно являє собою відносно стійку, внутрішньо визначену сутність об’єкта. За функціонального підходу якість - це відповідність стандартам або специфікації; відповідність 
запитам споживачів. За джерелом вимог виокремлюється виробничий (відповідність нормам і стандартам) і соціальний (відповідність запитам споживачів) аспекти якості. За широтою аналізу якість визначається як якість результатів, або як якість результатів, процесу та умов, у яких він відбувається [1].

Найбільш поширене тлумачення якості полягає в тім, що вона визначає міру цінності, вартості чого-небудь, його здатність задовольняти певні потреби, мету, норми тощо.

Водночас, здійснений системно - термінологічний аналіз категорії «якість освіти» дав нам змогу визначити іiі через сукупність таких аспектів: результативно-нормативного (відповідність якості підготовки випускників вимогам державних освітніх стандартів); процесуально-нормативного (відповідність якості процесу освіти нормам і вимогам); результативно-особистісного (відповідність якості випускників запитам споживачів освітніх послуг); процесуальноособистісного (відповідність якості освіти потребам, можливостям та інтересам суб' єктів освітнього процесу) [2].

На підставі здійсненого нами аналізу якість освіти визначено як міру відповідності процесу та результатів освіти вимогам держави, суспільства, запитам споживачів, потребам, можливостям та інтересам всіх суб'єктів освітнього процесу.

Якість вищої освіти ми розуміємо як збалансовану відповідність вищої освіти (як системи, процесу і результату) установленим потребам, вимогам, меті, нормам, стандартам, що визначаються окремими громадянами, організаціями, підприємствами, суспільством та державою загалом. При цьому складниками якості вищої освіти є: якість підготовки випускників ВНЗ як якість результату вищої освіти; якість державних освітніх стандартів, якість чинної нормативної бази, якість освітніх програм; якість матеріально-технічної, навчально-методичної, лабораторної бази вищої освіти; якість освітніх технологій; якість професорсько-викладацьких та науково-дослідницьких кадрів вищої школи; якість виховання; якість управління ВНЗ тощо [3].

Сутність професійної підготовки майбутніх фахівців у ВН3 означено нами як процес засвоєння студентами фундаментальних знань, набуття умінь, навичок, компетентностей, які забезпечують їх готовність до успішного виконання професійних функцій, виявлення реалізаційних здатностей особистості, потребу до постійної самоосвіти й саморозвитку.

() С. В. Мудра, 2014. 
Стрімкий процес глобалізації, посилення міжнародного розподілу праці та жорстока конкуренція у світовій економіці висувають на передній план питання якості освіти трудових ресурсів.

У широкому значенні «якість освіти» найчастіше розуміють як ступінь відповідності змісту, форм та засобів навчання та рівня освітньої підготовки випускників навчальних закладів очікуванням та потребам особистості, держави та суспільства. Країни Свропейського Союзу дієвим інструментом забезпечення якості освіти визнали компетентнісний підхід, який сьогодні утверджується в більшості європейських національних освітніх систем. Сформульовано чотири стратегічні надзавдання для сучасної європейської освіти: 1) навчити жити разом; 2) навчити вчитися; 3) навчити діяти; 4) навчити відповідати за власні вчинки та своє життя.

Для уточнення поняття скористаємося визначенням російських дослідників О. Н. Олійникової, А. А. Маравтевої, С. В. Коновалової, Є. В. Тартакової, які трактують поняття «компетентність» як спроможність особистості на основі органічної єдності набутих знань, умінь, досвіду та ставлень здійснювати як звичайну, так і нову діяльність у певній галузі.

Мета статті. Аналіз розвитку мовленнєвої компетентності як складової у структурі компетентностей на якість підготовки конкурентоздатних фахівців у ВНЗ України.

Сьогодні не викликає заперечень те, що освіта $є$ фундаментом переходу до інноваційної моделі розвитку економіки через підготовку якісного трудового потенціалу. Посилення зв'язку освіти й економіки, необхідність орієнтації освіти на потреби ринку праці висунули підвищені вимоги до якості підготовки фахівців у вищій школі. Основними ознаками поняття «якість» є: цілісність, ієрархічність, аксіологічність, мінливість, внутрішньо-зовнішня зумовленість, вимірюваність тощо.

На думку автора, поняття «компетентність» у контексті визначення кінцевої мети діяльності закладу освіти можна пояснити як набуту характеристику особистості випускника, яка, грунтуючись на певних ціннісних переконаннях, охоплює відповідні знання, уміння і навички та дає змогу застосовувати їх у самостійній практичній діяльності для реалізації власного життєвого потенціалу.

Рада Свропи визначила перелік 3 п'яти ключових компетентностей, якими необхідно озброїти молодих європейців в умовах розширення та інтеграції ринків праці, старіння населення континенту, зростання рівня міграції, безробіття i, як наслідок, 
посилення соціальної нерівності громадян:

1. Політичні та соціальні компетентності.

2. Компетентності, пов'язані 3 життям у мультикультурному суспільстві.

3. Компетентності, які стосуються володіння усним та писемним мовленням.

4. Компетентності, пов'язані 3 розвитком інформаційного суспільства.

5. Готовність та здатність учитися протягом усього життя.

Молодого європейця, який живе повноцінним життям в умовах глобалізації, важливо озброїти знаннями про те, як налагоджувати стосунки з іншими, працювати в команді (неоколективізм), розв'язувати конфлікти. Потрібно навчити випускника самостійно складати та реалізовувати життєві плани та персональні проекти, діяти незалежно 3 урахуванням суспільних норм, усвідомлювати наслідки своїх самостійних рішень і вчинків, захищати свої законні права, інтереси, потреби.

Поняття «компетентність» можна визначити як сукупність, єдність знань, умінь та ставлень у відповідному контексті, а ключові компетенції трактувати як такі, що потрібні індивідууму для особистісного розвитку, активного громадянства, соціальної інтеграції та зайнятості.

Європейська довідкова система називає вісім ключових компетентностей:

1. Спілкування рідною мовою.

2. Спілкування іноземною мовою.

3. Математична компетентність та базові компетентності в галузі науки та техніки.

4. Цифрова компетентність (компетентність у сфері сучасних інформаційно-цифрових технологій).

5. Уміння вчитися.

6. Міжособистісна, міжкультурна, соціальна та громадянська компетентність.

7. Підприємливість.

8. Культурна виразність.

Вітчизняна педагогіка має вже напрацювання в цьому напрямі. Проблему компетентності на різних рівнях аналізу розробляли С. Гончаренко (тлумачення явища компетентності), I. Тараненко (компетентність як здатність до найефективнішого застосування знань), А. Василюк (сучасні підходи до компетентності вчителів), К. Корсак (ㄷ) С. В. Мудра, 2014. 
(цивілізаційна компетентність), M. Михайличенко, В. Аніщенко (професійна підготовка НП основі стандарту компетентності).

Українські вчені по-різному тлумачать поняття компетентності. Найбільшого поширення в нашій науковій літературі набуло визначення компетентності як сукупності знань та умінь, необхідних для ефективної професійної діяльності: уміння аналізувати, передбачати наслідки діяльності, використовувати інформацію.

Компетентність - це загальна здатність, що грунтується на знаннях, досвіді, цінностях, здібностях і знаннях, здобутих завдяки навчанню.

У деяких працях вітчизняних дослідників натрапляємо на семантичні поняття: «компетентність» та «група компетентностей». Практично одним словом ми називаємо і загальну здатність і іiі компоненти, тобто складові групи компетентностей. У цьому можна підкреслити професійну компетентність людини, а можна виокремити конкретні складові, які переважно іії визначають.

На основі міжнародних та національних досліджень вчені Академії педагогічних наук України виокремили сім наскрізних для всіх рівнів освіти ключових компетенцій: навчальна, культурна, здоров'язберігаюча, інформаційно-комунікативна, соціальна, громадянська та підприємницька. Але особливе місце сьогодні посідає мовленнєва компетенція - це вміння адекватно й доречно, практично користуватися мовою в конкретних ситуаціях (висловлювати свої думки, бажання, наміри, міркування тощо), використовувати для цього як мовні, так і позамовні засоби (невербальну знакову систему) й інтонаційні засоби виразності мовлення.

При аналізі феномена мовленнєвої компетентності за основу беруться досягнення таких наук, як риторика, соціопсихолінгвістика, неориторика, етносоціопсихолінгвістика тощо, що дає змогу побачити у процесі мовленнєвої діяльності людини наявність мовних та мовленнєвих знань, умінь та навичок, на яких грунтується професійномовленнєва комунікація, власний повсякденний, соціальний, практично-технологічний, комунікативний, професійний досвід, інтелектуальні, художні й організаційні (лідерство, комунікабельність) здібності, моральні, етичні, релігійні та інші цінності. Визначено такі критерії оцінки показника «мовної й мовленнєвої компетенції та компетентність особистості»: досконале володіння й уміння правильно використовувати у процесі комунікації вербальні та невербальні знакові системи, норми мови і техніку мовлення. 
На мовну та мовленнєву компетентність впливають такі чинники:

- лексична компетенція - наявність певного запасу слів для обслуговування професійно-мовленнєвої й інших видів діяльності і спілкування; здатність до адекватного використання лексем, доречне вживання образних виразів (фігур і троп), приказок, прислів'їв, фразеологічних зворотів тощо.

- фонетична компетенція - правильна вимова всіх звуків рідної мови, звукосполучень згідно 3 орфоепічними нормами, наголосів, добре розвинений фонетичний слух, що сприяє диференціації фонеми; володіння інтонаційними засобами виразності мовлення (темп, тембр, сила і висота голосу, логічні наголоси тощо);

- граматична компетенція - уживання граматичних форм рідної мови згідно з законами й нормами граматики (рід, число, відмінок, кличний відмінок тощо), чуття граматичної форми, наявність корекційних навичок щодо правильності вживання граматичних норм;

- діамонологічна компетенція - володіння діалоговими i монологовими техніками спілкування, технікою ведення спору, технікою впізнавання невербальної знакової системи, технікою роботи 3 текстовим матеріалом тощо.

Що означає знати мову? Чи рівнозначні такі поширені в наш час поняття, як «вивчити мову» й «опанувати мову»?

Науковці не випадково розмежовують ці актуальні поняття. Відомо, що можна добре завчити правила i навіть свідомо застосовувати багато граматичних конструкцій, проте не бути здатним вільно, легко, влучно, доцільно, досконало й оперативно користуватися цими знаннями в різних комунікативних ситуаціях поза навчальним середовищем, тобто не досягти функційної грамотності. Опанувати мову - це непросто ії розуміти і знати, це мати здатність мобілізовувати набуті мовні знання для розв'язання певних комунікативних завдань у різних контекстах, ситуаціях, сферах навчальної, наукової та професійної діяльності, бо ж «знання про те, що треба робити, і саме діяння мають різні механізми, й одне не перекриває інше» [10]. До того ж не кожне знання логічно трансформується в навик, проте останній зазвичай формується через знання.

Отже, володіння мовою $є$ багатокомпонентним, складним, комплексним поняттям, яке передбачає й індивідуальне багатство словникового запасу того, хто говорить, і чистоту, ясність, точність, виразність, нормативність його мовлення, i розуміння нюансів 
значення спектру слів, і розрізнення мовних засобів за їх стилістичним забарвленням, і досконале володіння способами побудови текстів та речень різної структури засобами цієї мови, і знання національних особливостей формо- та словотворення й мовленнєвого етикету, а також уміння надати фонетико-інтонаційної виразності своєму усному мовленню. Мовна та мовленнєва компетентність стає потужним фактором у професійній підготовці конкурентоздатних фахівців, бо ж представники наукової й технічної еліти народу, його найосвіченіші верстви і мають стати носіями зразкової літературної мови в обох формах їі функціонування.

Дослідниками семіотики доведено, що «вивчення науки може бути цілком включене до вивчення мови, оскільки вивчення мови науки передбачає не просте усвідомлення іï формальної структури, але й вивчення iї відношення до позначуваних об'єктів, а також до людей, які використовують цю мову» [9]. Кожна держава прагне до зміцнення наукового інтелекту своїх громадян, який вербально відбиваєься i зберігається національною науковою мовою. Завдяки науковій мові як важливій складовій частині національної літературної мови, що виступає обов'язковим атрибутом держави та іï ознакою, підтримуються національна гідність, духовність народу i передаються у світовий інформаційний простір національні досягнення з різних галузей знань.

Вища освіта скерована на підготовку конкурентоздатних фахівців. Вжливими складовими такої підготовки має стати формування фахової культури мовлення, складовими якої, безумовно, $\epsilon$ мовна компетентність та комунікативна досконалість. Здобуття вищої освіти передбачає необхідність опанування поняттєвою сферою обраної спеціальності, вербально представленою засобами національної термінології (системою термінів у двох взаємопов'язаних сферах іiі існування: фіксації та функціонування) і діловою фразеологією професійного спілкування в іiі парадигматичних i синтагматичних зв’язках. Два функціональні стилі національної літературної мови науковий та офіційно-діловий - у їх сучасному стані і складають предмет навчання мови спеціальності в закладах вищої освіти.

Компетентісна освіта зорієнтована на практичні результати, досвід особистісної діяльності, вироблення ставлень, що зумовлює принципові зміни в організації навчання, яке стає спрямованим на засвоєння конкретних цінностей та життєво необхідних знань і вмінь. У цьому контексті сьогодні змінюються і підходи до оцінювання 
результатів начальної діяльності як складової навчального процесу. Метою навчання мають бути сформовані компетенції, які розуміються як загальна здатність, що грунтується на знаннях, досвіді та цінностях особистості. Компетентісний підхід на перше місце ставить не поінформованість особистості, а вміння на основі набутих знань розв'язувати проблеми, які виникають у різних ситуаціях.

Удосконалення освітнього процесу 3 позиції компетентнісного підходу полягає в тому, щоб навчити учнів застосовувати набуті знання й уміння в конкретних навчальних та життєвих ситуаціях.

Майбутня професійна діяльність конкурентоздатних фахівців випускників ВНЗ вимагає від них не тільки професійної майстерності, а й широкої загальної освіти, оскільки вона пов'язана 3 інтенсивним усним і писемним спілкуванням, передбачає широку мовленнєву практику, потребує точного вираження понять і категорій у різних сферах професійної діяльності.

Під час виконання своїх безпосередніх обов'язків фахівець виступає в різних комунікативних ролях: веде ділове листування, складає законопроекти, проекти постанов, договори й угоди, спілкується 3 іншими фахівцями та громадянами різного рівня культури. Недотримання й порушення мовних норм може стати причиною непорозуміння, викликати заперечну реакцію у співрозмовника i негативно позначитися на його подальшій кар'єрі [7, с. 3].

Мовленнєва компетентність - це поєднання мислення і мови, точність вираження думок, почуттів, ясність, зрозумілість смислових зв'язків і відношень одиниць мови в мовленні зв'язкам і відношенням предметів і явищ у реальній дійсності. Культури мовлення, як i культури спілкування, потрібно навчати на всіх етапах підготовки, перепідготовки конкурентоздатних фахівців.

\section{Література}

1. Ожегов С. И. Словарь русского языка / С. И. Ожегов - М. : Изд-во «Советская энциклопедия», 1973. - С. 847.

2. Радомская М. В. Единый государственный экзамен в обеспечении качества общего образования : дис. ... канд. пед. наук / М. В. Радомская. - Таганрог, 2006. - 148 с.

3. Библиотека авторефератов и диссертаций по педагогике [Электронный ресурс]. - Режим доступа : http://nauka-pedagogika.com

4. Субетто А. И. Квалиметрия человека и образования (методология и практика): итоги, проблемы, направления / А. И. Субетто // Материалы симп. «Квалиметрия в образовании: методология и практика». - М. : ИЦПКПС, 2002. - С. 175.

5. Елисеева Т. Качество образования : методологические основания дискуссии / 
Т. Елисеева, Б. Батурин // Высшее образование в России. - 2005. - № 11. - С. 11-17.

6. Федько А. В. Якість освіти як філософія та педагогіка розуміння доцільного / А. В. Федько, Ю. М. Федько // Вища освіта України. - 2006. - № 1. - С. 170-171.

7. Мельникова К. І. «Паблік Рілейшнз» як функція управління в органах державної влади / К. І. Мельникова, С. С. Рязанова // Актуальні проблеми державного управління : наук. зб. - Харків : УАДУ Харківський філіал, 1999. - № 2. - С. 40-46.

8. Веніг Н. Мовленнєва культура учнів / Н. Веніг // Обдарована дитина - 2000. № 4. - C. 18-20.

9. Веніг Н. Художній образ і мовна особистість / Н. Веніг // Франція та Україна, науково-практичний досвід у контексті діалогу національних культур : тези доповідей. - 2000. - Т. 2. - С. 15-17.

10. Методика навчання іноземних мов у середніх навчальних закладах // [за ред. К. І. Онищенко]. - К., 1999. - 227 с.

Стаття надійшла до редакиії 26.10.2014 p. 